\title{
Sorption of surfactants on silica gel in conditions of ascending thin-layer chromatography with micellar mobile phases
}

\author{
L.P.Loginova, D.V.Yedamenko \\ V.Karazin Kharkiv National University, \\ 4 Svobody Sq., 61022 Kharkiv, Ukraine
}

Received April 4, 2014

\begin{abstract}
The paper is devoted to estimation of the presence of micellar front on the plates with polar sorbent. It has been found that at elution by solutions of CPC and non-ionogenic Twin-80 on the plates with polar silica gel three fronts are formed: first one is visually observed front of solvent; second one is observed at UV-irradiation and corresponds to the water solution of surfactant monomers and third one corresponds to micelles of surfactant and is observed at erythrosine staining. The received results permit to describe the mechanism of chromatographic separation of analytes, which differs from the mechanism in micellar TLC with an non-polar stationary phase. It was shown that the process of separation of substances with micellar mobile phase is complex from the viewpoint of mechanism of separation: while initially substance is separated within three-phase system, finally it became separated within two-phase system.
\end{abstract}

Оценено присутствие мицеллярного фронта на пластинах с полярным сорбентом. Установлено, что при элюировании растворами ЦПХ и неионогенным Твин-80 на пластинках с силикагелем происходит образование трех фронтов: первый - визуально обнаруживаемый фронт растворителя; второй - наблюдаемый при УФ-освещении и относящийся $\mathrm{\kappa}$ водному раствору мономеров ПАВ и третий - относящийся $\kappa$ мицеллам ПАВ и наблюдаемый при окрашивании эритрозином. Полученные результаты дают возможность описать механизм хроматографического разделения аналитов, который отличается от механизма в мицеллярной ТCX с неполярной стационарной фазой. Показано, что разделение веществ с мицеллярной подвижной фазой происходит в двух системах: вначале вещество распределяется в трехфазной системе, затем в двухфазной.

Сорбція поверхнево-активних речовин на силікагелі в умовах висхідної тонкошарової хроматографії з міцелярними рухомими фазами. Л.П.Логінова, Д.В.ЄӘаленко.

Оцінено присутність міцелярного фронту на пластинах з полярним сорбентом. Встановлено, що при елююванні розчинами ЦПХ та неіоногенним Твін-80 на пластинках з силікагелем відбувається утворення трьох фронтів: перший фронт розчинника, що візуально виявляється; другий - спостерігається при УФ-опроміненні та відноситься до водного розчину мономерів ПАР та третій - той, що відноситься до міцел ПАР і спостерігається при забарвлюванні еритрозином. Отримані результати дають можливість описати механізм хроматографічного розділення аналізів, які відрізняється від механізму в міцелярній ТШХ 3 неполярною стаціонарною фазою. Показано, що розділення речовин з міцелярною рухомою фазою відбувається у двох системах: спочатку речовина розподіляється у трифазній системі, а потім у дво

фазній. 


\section{Introduction}

One of the promising fields of the thinlayer chromatography (TLC) as liquid chromatography (LC) in whole in the few last decades is connected with use of new type of mobile phases - lyophilic nanodispersed systems. Examples of the last include solutions of surfactants with diphilic ions or molecules able to self-aggregation in solutions with formation of micelles and other nano-sized surfactant aggregates (vesicles, bilayers, admicelles, hemimicelles) [1].

Micellar solutions of surfactants were proposed at first as mobile phases for TLC [2] and High-performance liquid chromatography (HPLC) [3, 4] by Armstrong et al. Mobile phases of this type have a range of practical advantages as compared to traditional for LC mixtures of solvents (micellar solutions of surfactants are non-volatile, uninflammable and non-toxic), and also provide new possibilities for control of selectivity of chromatographic separation [4]. Mechanism of chromatography in micellar LC (MLC) supplemented by new interphase processes - separation of substances between mobile phase solvent and pseudophase of micelles with characteristics of separation individual for each substance.

An important factor determining the specificity of chromatographic separation by means of micellar mobile phases is surfactant adsorption on the surface of stationary phase during contact with mobile phase. Due to diphility of surfactant monomers, their adsorption is possible on the surfaces of both polar (such as silica gel) and nonpolar (such as grafted silica gel) stationary phases.

As a result of surfactant adsorption from mobile phase, properties of the surface of the stationary phase change; for instance, polarity can become as smaller (for silica gel-based stationary phases), so greater (for reverse phases). So, at use of micellar mobile phase elution order can become reversed as compared with elution of mixture of solvents on the same initial stationary phase [5].

The fact that in planar chromatography adsorption of surfactant on the stationary phase leads to formation of two solvent fronts was discussed already in the first publications dedicated to use of micellar mobile phases in TLC [6]. First front of the solvent was attributed to the aqueous-solvent containing surfactant monomers (at concentration lower than critical micelle concentration (CMC)), the second one, sufficiently less mobile - to surfactant micelles.
The boundary of the second front was observed directly on the chromatogram at UVirradiation [6]. Later E.Sumina for visualization of the front of cationic surfactant micelles of cetyltrimethylammonium bromide has used metal complex of Sn (IV) with pyrocatechol violet which is blue in presence of micelles and red in premicellar solutions containing only surfactant ions [7].

The fact of formation of multiple fronts in TLC was known earlier; this effect was described for multicomponent mobile phases of conventional type consisting of solvents with different eluting power [8]. However, in the case of the front of micellar pseudophase the specificity of situation is determined by the fact that during the process of chromatogram development aggregative state of mobile phase changes and from ultramicroheterogeneous it becomes homogeneous. This process must be accompanied by changes in the mechanism of chromatographic separation because the substance eventually became separated not in the three-phase (surfactant micelles - solution of mobile phase - stationary phase), but in two-phase system without surfactant micelles. So, the question arises, to what extent separation of substances in planar chromatography with micellar mobile phase corresponds with well-known three-phase model proposed by D.Armstrong for description of the processes in the MLC [9] that does not suggest formation of the second front.

The most part of experiments on TLC separation of the substances with use of micellar mobile phases were carried out on the plates with non-polar or low-polar stationary phase $[2,7,10]$; observation of the second front of the solvent is also related mostly to these samples. Earlier we have described micellar mobile phases providing TLC separation for the number of substances on the most common plates with polar stationary phase based on the silica gel $[5,11]$. In all these cases neither threephase model [9], nor other models of separation in MLC [12] turned out to be useful for choice of factors having influence on the retention of substances. So, despite the premises of the model, characteristics of retention of substances did not depend practically on the surfactant concentration in mobile phase.

The objective of this paper consisted in determination of the features of the micellar pseudophase front formation as well as 


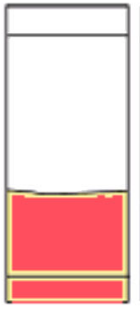

1

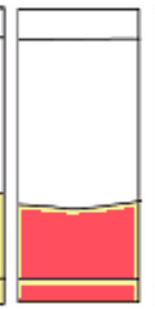

2

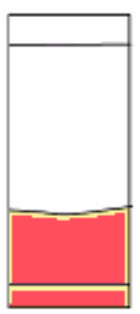

3

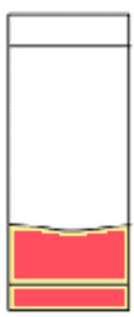

4

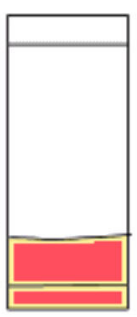

5

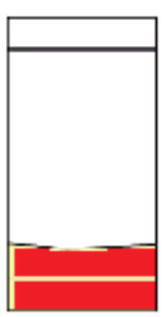

6

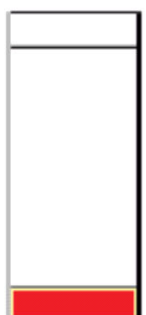

7

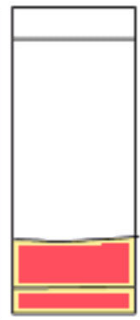

8

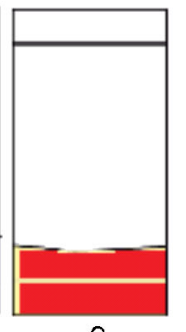

9

Fig. 1. Front of the micellar fraction of mobile phase on the chromatographic plates "Sorbfil" PTSH-AF-A-UV (with erythrosine as developer). Composition of mobile phases is shown in the Table.

Table. Retardation factors for micellar pseudophase (third front) on the plates "Sorbfil" PTSHAF-A-UV

\begin{tabular}{|c|c|c||}
\hline No & Composition of mobile phases & $\bar{R}_{f} \pm t_{P, f} \times S_{\bar{R} f}$ \\
\hline 1 & $1 \cdot 10^{-2} \mathrm{~mol} / 1$ of Tween-80 & $0.37 \pm 0.02$ \\
2 & $1 \cdot 10^{-2} \mathrm{~mol} / 1$ of Tween-80,3\% (v/v) of 1-propanol & $0.36 \pm 0.02$ \\
3 & $1 \cdot 10^{-2} \mathrm{~mol} / 1$ of Tween-80, $1 \%(\mathrm{v} / \mathrm{v})$ of 1 -butanol & $0.36 \pm 0.02$ \\
4 & $1 \cdot 10^{-2} \mathrm{~mol} / \mathrm{l}$ of Tween-80, 0.3 \% (v/vv/v) of 1-pentanol & $0.27 \pm 0.02$ \\
5 & $1 \cdot 10^{-2} \mathrm{~mol} / 1$ of CPC & $0.20 \pm 0.01$ \\
6 & $5 \cdot 10^{-3} \mathrm{~mol} / \mathrm{l}$ of CPC & $0.12 \pm 0.02$ \\
7 & $1 \cdot 10^{-4} \mathrm{~mol} / \mathrm{l}$ of CPC (premicellar range of concentrations) & No line of the third front \\
\hline
\end{tabular}

its role in separation of substances under conditions of ascending TLC with use of micellar mobile phase and silica gel as stationary phase.

\section{Experimental}

In the work as stationary phases plates for thin-layer chromatography Sorbfil UV254 (ZAO Sorbpolimer, Russia, $10 \times 10 \mathrm{~cm}$ ) were used. For obtaining of mobile phases surfactants cetylpyridinium chloride (CPC, Merck, mass fraction of main component 99-101 \%) and Tween-80 (AppliChem $\mathrm{GmbH}$, density - $1.074 \mathrm{~g} / \mathrm{cm}^{3}$ ) with additives of aliphatic alcohols: 1-propanol (p.a., Makrohim), 1-butanol (p.a., Makrohim) and 1-pentanol (Reahim, p., additionally purified by distillation; fraction boiled at $78.5^{\circ} \mathrm{C}$ ) were used. Ascending eluting was carried out in glass chambers for chromatography. For visualization of the front of micellar pseudophase solution of erythrosine with mass fraction of $1 \%$ was used.

\section{Results and discussion}

In the work micellar mobile phases with composition chosen earlier for TLC separation of mycotoxins and parabens on the plates with silica gel were used [5], namely, the solutions of cationic surfactant CPC, nonionic surfactant Tween-80 with additives of aliphatic alcohols or equimolar mixture of CPC and Tween-80 at concentrations of surfactant higher than CMC. For comparison at investigation of the solvent front position, solution of CPC with concentration much lower than CMC was used as well (Table).

During development of the methods of separation and determination of mycotoxins and parabens on the plates with silica gel, chromatograms were analyzed at UV-irradiation with wavelength of $254 \mathrm{~nm} \mathrm{[5].} \mathrm{At}$ UV-irradiation of the plate with background emission, line of the second front bordering the region of emission with lower intensity and situated slightly lower than the first, visible front of solvent was observed [5]. Primarily this boundary, in accordance with literature data, was attributed by us to movement of the front of micellar pseudophase [5]. However such interpretation became discussable when independence of retardation factors of separated substances on surfactant concentration in mobile phase was revealed [5]. So, the values of surfactant concentrations in mobile phases [5] 
were chosen not from the reasons of selectivity, but from additional requirements (shape and size of chromatographic spots, time of chromatogram development).

In the present work for visualization of the front of micellar pseudophase erythrosine dye able to be bound by surfactant micelles was used [13]. After scending elution with corresponding surfactant-containing mobile phase all plated were sprayed by dye solution. Only lower part of the plate became stained (Fig.). So, at elution with micellar mobile phase on the plates Sorbfil UV-254 three fronts are formed: the first one, observed visually, corresponds probably to the solvent (water). The second one, observed at UV-irradiation, corresponds to surfactant solution without micelles and is similar to the actual front for mobile phases consisting from organic solvents [8]. The third front presented by the boundary of erythrosine-stained region corresponds to movement of micellar pseudophase retarding sufficiently from the front of phase (Fig.).

Front of the micellar fraction (third front) is characterized by values of retardation factor $R_{f}$ calculated in the same way as the retardation factor of separated substances (Table).

As follows from the Table, distance passed by pseudophase does not reach even one half of the path length of the first front, it increases at increase of CPC concentration as well as at transition from cationic CPC to nonionicTween-80 taken at the same concentration and decreases at addition of 1-pentanol to micellar solutions of Tween-80. If mobile phase contains the mixture of nonionicTween-80 and cationic CPC front of pseudophase of mixed micelles is characterized by the same value of retardation factor as in the case of individual CPC solutions with the same concentration.

Obtained data showing low mobility of micellar pseudophase on the silica gel are consistent with results obtained by D.Armstrong despite the fact that the last ones correspond to reverse phase type of TLC on the plates with polyamide sorbent and mobile phase based on cationic surfactant. Micellar pseudophase has made the second front visible at UV-irradiation and situated slightly lower than one half of the distance from the start line to the line of the first front. With increase of surfactant concentration path length of the micellar front also increases [14].
Limited mobility of micellar pseudophase under conditions of TLC is determined by adsorption of surfactant on the silica gel at ascending movement of mobile phase. The features of adsorption of surfactants of different charge types on the surface of silica gel were characterized in the papers of A.Berthod, S.Parida et al. [15-19]. It is well-known that cationic surfactants are sorbed on the surface of silica gel as from micellar, so from premicellar solutions [20]. Adsorption of cationic surfactants is determined first of all by electrostatic interaction between ionic heads of surfactants and active silanol groups on the surface of silica gel and leads to neutralization of the surface charge. Since hydrocarbon radicals of adsorbed surfactant monomers turned out to be oriented towards the solution, sorption is accompanied by surface aggregation of surfactant due to hydrophobic interactions between surfactant monomers [21]. Meanwhile, on the surface of silica gel complex aggregates of surfactant molecules, such as admicelles, hemimicelles, bilayers, reverse hemimicelles are formed [20].

Adsorption of nonionic surfactant from solution on the polar surface of silica gel is determined by formation of hydrogen bonds between silanol groups of silica gel and oxy ethylene chains of nonionic surfactant. So, nonionic surfactants are sobbed on the silica gel in the less degree then cationic ones. Adsorption of nonionic surfactants is described by sorption isotherm, which initial stage looks like the Langmuir monomolecular adsorption isotherm, while at increase of surfactant concentration less ordered occupancy of the surface typical for polymolecular adsorption takes place [21].

Adsorption of cationic and nonionic surfactants on the silica gel depends on the number and strength of adsorption centers: surface aggregation accompanies adsorption of surfactants on the strong adsorption centers of silica gel $[20,21]$.

So, as in the normal phase, so in the reverse phase type of TLC at ascending eluting "layering" of micellar mobile phase similar to the processes described earlier for multicomponent mixtures of solvents in common TLC [8] takes place.

From the viewpoint of low mobility of micellar fraction and position of its front it can be deduced why the mobility of separated substances did not change at variation of surfactant concentration in mobile phase, for instance, at parabenes separation [5]. As mobile phase micellar solution of $1 \cdot 10^{-2} \mathrm{~mol} / 1$ 
of Tween-80 containing $0.3 \%(v / v)$ of 1 pentanol was used. Sequence of chromatographic zones of methyl-, ethyl-, n-propyland $n$-butylparabenes corresponds to the reverse type of TLC: the least movable was hydrophobic $n$-butylparabene $\left(\log K_{o / w}=\right.$ 3.60 [22]), the most movable was the least hydrophobic methylparabene $\left(\log K_{o / w}=\right.$ 1.95 [22]). Parabenes are partially bound by micelles of nonionic surfactant; so, logarithms of their constants of binding by micelles Bridge-35 are from 2.09 (methylparabene) to 2.50 ( $n$-butylparabene) [22]).

At elution of parabenes by micellar solution of $1.0 \cdot 10^{-2} \mathrm{~mol} / 1$ of Tween- 80 containing 1-pentanol, front of micellar pseudophase is observed at $R_{f}=0.27$ (Table), while for the most retained butylparabene $R_{f}=$ 0.42. Zones of all parabenes are revealed above the line of the front of micellar fraction, so after some time, separated substances moved not with micellar mobile phase, but with solution containing surfactant monomers (the last hydrophobize the surface of silica gel). At the same time from the processes determining the retaining of parabenes is excluded the separation of parabenes between solution and micelles of mobile phase, in this case concentration of micelles and so concentration of surfactant loses its influence on the retaining of substances. Moreover, practically the same values of $R_{f}$ were observed at eluting of parabenes by solutions of surfactants with concentrations in the premicellar range [5].

\section{Conclusions}

Under conditions of ascending TLC with use of micellar mobile phase (solutions of CPC cationic and Tween-80 nonionic surfactants) and silica gel as stationary phase sufficient retardation of micellar fraction of mobile phase occurs which is determined by adsorption and surface aggregation of the surfactants on the silica gel. At ascending elution by solutions of CPC and nonionic Tween- 80 on the plates with silica gel and UV-coating formation of three fronts is observed: first one is visually observed front of solvent; second one is observed at UV-irradiation and corresponds to the solution of surfactant monomers and third one corresponds to micelles of surfactant and is observed at erythrosine staining.

Distance passed by micellar pseudophase does not reach even one half of the free path of the first front and increases at increase of CPC concentration. In compliance with adsorption specificity for cationic and nonionic surfactants on the silica gel, front of micelles for nonionicTween-80 is higher than the front of cationic micelles of CPC and mixed micelles of CPC-Tween-80.

Substances, for which retaining does not depend on the concentration of surfactant in the mobile phase are eluted above the line of the third front. So, at some moment of eluting micelles of mobile phase are excluded from the processes of substance separation. As result, process of TLC separation of substances with micellar mobile phase is complex from the viewpoint of mechanism of chromatographic separation: at the first stage substance is separated within threephase system (part of mobile phase-surfactant micelles of mobile phase-stationary phase covered by surfactant aggregates), while at the second stage - within twophase system (mobile phase-stationary phase hydrophobized by adsorbed surfactant monomers).

\section{References}

1. K.Holberg, B.Yensson, B.Cronberg, Surfactants and Polymers in Water Solutions, Bionom, Moscow (2007) [in Russian].

2. D.W.Armstrong, R.Q.Terril, Anal.Chem., 51, 2160 (1979).

3. D.W.Armstrong, S.J.Henry, J.Liq.Chromatogr., 3, 657 (1980).

4. A.P.Boichenko, L.P.Loginova, A.U.Kulikov, Meth. and Objects Chem. Anal., 2, 92 (2007).

5. L.P.Loginova, D.V.Yedamenko, A.U.Kulikov et al., Khark.Univ.Bull.Chem.Ser., 731, 127 (2006).

6. D.W.Armstrong, M.McNeely, Anal.Lett., 12, 1285 (1979).

7. E.G.Sumina, S.N.Shtykov, N.V.Tyurina, Sorpt. Chromatogr. Proces., 4, 750 (2004).

8. F.Geiss, Fundamentals of Thin Layer Chromatography (Planar Chromatography), Scientifical Council RAS in Chromatography, v.II, Moscow (1999) [in Russian].

9. D.W.Armstrong, F.Nome, Anal.Chem., 53, 1662 (1981).

10. S.N.Shtykov, E.G.Sumina, N.V.Tyurina, $Z h$. Rus. Khim.Obsh., 47, 119 (2003).

11. D.V.Yedamenko, L.P.Loginova, A.I.Pugach et al., Khar.Univ. Bull.Chem.Ser., 731, 147 (2007).

12. L.P.Loginova, L.V.Samokhina, A.P.Boichenko et al., J. Chromatogr. A, 1104, 190 (2006).

13. N.O.Mchedlov-Petrosyan, Differentiation of the Strength of Organic Acids in True and Organized Solutions, V.Karazin Kharkiv National University, Kharkiv (2004) [in Russian].

14. D.W.Armstrong, K.H.Bui, J. Liq.Chromatogr., 5, 1043 (1982).

15. A.Berthod, I.Girard, C.Gonnet, Anal.Chem., 58, 1356 (1986). 
16. A.Berthod, I.Girard, C.Gonnet, Anal.Chem., 58, 1359 (1986).

17. S.Parida, S.Dash, S.Patel et al., Adv.Coll.Interface Sci., 77, 110 (2006).

18. K.Esumi, T.Nagahama, K.Meguro, Coll. Polym.Sci., 269, 1274 (1991).

19. H.Rupprecht, T.Gu, Coll.Polym.Sci., 269, 506 (1991).
20. J.R.Torres-Lapasio, Micellar Liquid Chromatography, Marcel Dekker, New York (2000).

21. N.O.Mchedlov-Petrosyan, A.V.Lebed, V.I.Lebed, Colloidal Surfactants: Educational and Methodical Grant, V.Karazin Kharkiv National University, Kharkiv (2009) [in Russian].

22. A.S.Vlasenko, L.P.Loginova, E.L.Iwashchenko, J.Mol. Liq., 145, 182 (2009). 